\title{
Leadership and spirituality
}

\section{Robert Burke}

Robert Burke is Program Director at Melbourne Business School, Mt Eliza Centre for Executive Education, Mount Eliza, Australia.

\begin{abstract}
Purpose - This paper seeks to suggest that effective leadership can be achieved by, and can drive, an integral spiritual connectedness between governments, organisations and society as a whole.

Design/methodology/approach - A literature search to map the history and the underlying philosophies that have led to the current popular concept of leadership, and to suggest a different worldview to bring about a change to these underlying philosophies in order to enhance leadership effectiveness.

Findings - Effective leadership is multi-disciplinary, involving not only those disciplines of sociology, psychology and technology, but that of spirituality as well. This new approach is effective because of the different ways it offers of gaining deeper insights into a leader's own spiritual self, but also beyond this to others with whom the leader interacts, and others who are affected by the results of their leadership.
\end{abstract}

Research limitations/implications - The paper is not an exhaustive literature search and is primarily limited to selected authors of futures studies, psychology, psychotherapy, economics and business.

Practical implications - The paper proposes steps to guide how organizational leadership can lead to more effective workplaces as well as benefiting the global society as a whole.

Originality/value - The paper is current in today's environment and offers a practical epistemological explorative approach into what effective spiritual leadership could mean and to consider the impact of leadership decisions and actions as a result.

Keywords Leadership, Psychology

Paper type Literature review

\section{Introduction}

Could spirituality produce better organizations and thus benefit society as a whole? This paper argues that it can. The aims and scope of this paper are to propose that through applying futures thinking centered on a higher level of consciousness about what kind of world we want to live and work in involves leaders to search for meaning and purpose beyond just that of material satisfaction. It also proposes that a connection with our spiritual selves allows what Wilber, Graves, Beck and others (Wilber, 2003, p. 118) refer to as "beyond flatland" a holistic integral (second tier) as well as transpersonal connections (third tier) leadership leading to effective leadership outcomes of value, not only to organizations, but to the global collective as a whole.

The paper argues that we need to have an understanding of how our current views on leadership were formed, both from macrohistory and from the patterns and scripts that have been prescribed for us over many centuries, to be able to differentiate from them in order to change them into an effective leadership paradigm.

The current practice of leadership does not appear to solve any of the major issues facing us today. Differences are still approached by negative conflict, often leading to war which creates global anxiety, and our current leaders pay little more than lip service to the humanitarian tragedies of today such as poverty, starvation, preventable diseases, and 
environmental destruction. Our leaders have still not demonstrated that these tragedies are not to be tolerated. Indeed, it can be argued that current practices of leadership are accelerating these detrimental impacts and that this intolerance is threatening our planet as a whole and all its life forms including human life itself. Whilst ever our economy is based on exponential population growth, greed, hegemonic dominance, and the growth of material consumption, this will continue to be the outcome. Indeed, are we anymore civilized in the twenty first century than we were in the first? Evidently not. Wars are still prevalent, as are malnutrition and starvation, and "leaders" are still, centuries on, reverting to the same methods that have been employed throughout history, with little changes except that of the ever increasing, devastating, detrimental effectiveness of modern warfare and our "righteous" approach to our shared environment to be used solely for human exploitation.

A spiritual leadership approach asks fundamentally different questions about what it means to be human, what we really mean by growth, and what values and power distributions are needed to enhance both organizations and society as a whole.

My approach to the subject of leadership and spirituality is not from a religious standpoint; although for many, religious faith plays a significant role being, for them, where spirituality lies. My position on spirituality is more from a sense of connectivity, a relationship, such as what James Lovelock (2006, p. xi) calls "Gaia", a metaphor for the living earth, an ecological relationship, and others nonlocality (Laszlo, 2006:13) "nonlocal connections", or what Sarkar calls microvita. Inayatullah (www.ru.org/102-subodh.htm) states that for Sarkar:

... microvita are entities that exist between conception (mental realities) and perception (physical realities). In their crudest forms, they are viruses.

My approach takes into account those things which can be readily understood rationally and those things we don't necessarily have a rational explanation for, but nevertheless have an intuitive relationship with, such as some physical places.

Spirituality and its connection with science were illustrated by John Barrow when being interviewed by Fran Kelly on Australia's national broadcaster ABC Radio National Breakfast program on March 16, 2006. On March 15, 2006 Barrow was awarded the US\$1.4 million Templeton prize in the area of science and religion. The prize was awarded by the Duke of Edinburgh at Buckingham Palace on May 3, 2006. Barrow is professor of mathematical sciences at Cambridge University, and Professor of Astronomy at Gresham College in London, a position once held by Sir Christopher Wren.

The Science and Spirit publication, reported on their website (www.science-spirit.org/ webexclusives.php?article_id=616) March 15, 2006, that Barrow:

... used insights from mathematics, physics, and astronomy to set out wide-ranging views that challenge scientists and theologians to cross the boundaries of their disciplines in order to fully realize what they may or may not understand about how time, space, and matter began; about the behavior of the universe (or, perhaps, "multiverses"); and about where it is all headed, if anywhere.

In his remarks at the news conference on March 15, 2006, Barrow said:

Our scientific picture of the universe has revealed time and again how blinkered and conservative our outlook has often been, how self-serving our interim picture of the universe, how mundane our expectations, and how parochial our attempts to find or deny the links between scientific and religious approaches to the nature of the universe.

Also in March 2006 Ervin Laszlo's new book Science and the Reenchantment of the Cosmos was launched. Laszlo, who was nominated for the Nobel Peace Prize in 2004 and 2005, is the holder of the highest degree of the Sorbonne as well as four honorary PhDs, and explains in this book how physical reality and spiritual reality are indeed two faces of one coherent whole (back cover):

What scientists are now finding at the outermost frontiers of every field is overturning the basic premises of Western civilization concerning the nature of matter and reality. 
Both these events perhaps marked a shift in an acceptance of a new(er) understanding of the convergence of science and spirituality in mainstream thinking as witnessed by the wide media attention Barrow, for science, received and in the world of futures studies Laszlo receives.

How different the response to Barrow and Laszlo was the response that René Descartes, the champion of rationalism, received on the publication of his Discourse of Method (1637). Blackburn (1999, p. 37-40) reported all that was necessary, for Descartes, was intense self examination and intense reason, and, through this process, all would be revealed. In response to Descartes view Antoine Arnauld (1612-94) accused Descartes of arguing in a circle - the infamous "Cartesian Circle" - where Descartes is committed to two different priorities, one being that knowledge is achieved by rational insight only and is known as "a priori", it can be seen to be true immediately, without any experience of the way of the world, and the other is Descartes "reasoning" about "God" with his "trademark argument" Cogito Ergo Sum "I Think, Therefore I Am":

Looking in to his own "self", which is all that he has at this point, Descartes discovers that he has an idea of perfection. He then argues that such an idea implies a cause. However, the thing that caused it must have as much "reality", and that includes perfection, as the idea itself. This implies that only a perfect cause, that is God, will do. Hence God exists, and has left the idea of perfection as an innate sign of his workmanship in our minds, like a craftsman leaving a trademark stamped in his work. (Blackburn, 1999, pp. 37-40)

Barrow and Laszlo claim to have converged science and spirituality with scientific proof, which Descartes was unable to do, and they have concluded that the two are integral to each other and not separate from each other. This "reemergence" has been debated and researched primarily as a postmodern discourse although the discourse on unconsciousness (often associated with the "spirit") can be seen as a modernist development (Watson, 2005, p. 718) from which much of the newer research into what we believe spirituality may mean emerged.

Watson (2005, p. 703) sights George Eliot's (Mary Ann Evans) translation of David Friedrich Strauss's book The Life of Jesus, Critically Examined as an example of one of the beginnings of the sustained onslaught in the late nineteenth century on both Christianity and Islam (Watson, 2005, p. 717) and the placement of spirituality into a rationalist or modernist domain. In this domain spirituality from Sarkar's and Laszlo's perspective is not readily amenable to rationalist analysis as in the late nineteenth century until very recently there was no rational "proof" that spirituality existed in science.

The suggestive evidence that it does now exist, according to Laszlo (2006, p. 13), has been validated as "teleportation experiments" showing the existence of "nonlocal connections" by both physicists at the National Institute of Standards in Colorado and by the University of Innsbruck in Austria.

Perhaps additional suggestive evidence of nonlocal connections is that associated with mindfulness. I believe it could be argued there is a possible link with mindfulness, leadership and spirituality.

Three examples for this belief being first, the article in General Science, January 27, 2006, reporting that people who meditate grow bigger brains than those who don't, this report claims that researchers at Harvard, Yale, and the Massachusetts Institute of Technology have found the first evidence that meditation can alter the physical structure of our brains. Brain scans they conducted reveal that experienced meditators boasted increased thickness in parts of the brain that deal with attention and processing sensory input (www.physorg.com/news10312.html).

The second example is that of Matthew Bambling, of the School of Medicine, at the University of Queensland, Australia where he writes (2006, p. 57):

Some of the best known mindfulness techniques are meditation, guided imagery and concentration. Studies show: 
- 87 percent less heart disease;

- 55.4 percent less tumours;

- 50.2 percent less hospitalization;

- 30.6 percent less mental disorders; and

- 30.4 percent less infectious diseases.

The third example being Zohar and Marshall (2000) who report on the anatomy and functioning of the brain and suggest that recent studies in neural oscillations leads to a third kind of thinking of which the brain is capable - unitive thinking. A chapter is devoted to the significance of the brain's $40 \mathrm{~Hz}$ neural oscillations; what different brain wave patterns mean, and the more profound question of where does consciousness come from and the chapter dealing with the "God spot" in the brain, identified by neurobiologists Persinger and Ramachandran, and the varieties of spiritual experiences emanating there from, lead the authors to make some intriguing connections with human behaviors (Bullock, 2002).

The organizational leadership that we have predominately experienced since the end of World War 11 emerged from the Cartesian-Newtonian worldview, described above, and was predicated on man's mastery of nature (enshrined in Newton's principle of cause and effect and the rationalist philosophies of Descartes), the "holistic" philosophy of the latter denigrates the manipulation of the environment to man's ends. Hames and Callanan (1997) even consider that we have the neat linear equations and elegant hierarchies of the Newtonian-Cartesian worldview to thank for conventional management myths. This developed into the twentieth century organizational worldview and in this domain any spirituality associated with organizations has been the spirit of capitalism. Ralston-Saul (2005, p. 36) asked the question is economics religion?:

There was little hint until the mid-nineteenth century that economics might be transformed into the source of civilizational truth. Only when God was said to have died did various leaders, professions and sectors risk pushing themselves forward as successors.

This question may not have been explicit before Ralston-Saul sighted it, but I contend that it may well have been implicit in our understanding of economics and organisations. In a recent article (Burke, 2006, pp. 71-82)) I posed the question do we have a dilemma, that being was the economy designed to be of service to humanity, or have we designed humanity to be of service to the economy?

Perhaps we can find an argument for this from Max Weber (1864-1920) in his essay Die protestantische Ethik und der Geist des Kapitalismus, 1904-05, translated into English in 1930 as The Protestant Ethic and the Spirit of Capitalism. Weber associated capitalism with Protestantism arguing that religious devotion was usually accompanied by rejection of worldly affairs, including the pursuit of wealth and possessions. Why was that not the case with Protestantism? The answer for Weber became associated with the Protestant work ethic which in turn became the accepted organizational paradigm we experience today - only today it includes non Protestants as well. (http://en.wikipedia.org/wiki/ The_Protestant_Ethic_and_the_Spirit_of_Capitalism)

\section{What could be the implications for organizational leadership of spirituality?}

This is a leadership challenge - how to demonstrate performance management (rational analyses) and at the same time put this into the context of purpose and meaning attribution (rational analyses but also including non-rational "connectivity"). Inayatullah (2005, p. 99) says:

A living organization without inspiration or microvita does not last (employee burn out, fatigue, loss of purpose). Microvita are a mysterious ingredient that helps to move the organization from data to information to knowledge to wisdom. Most importantly they act as a trigger to create an organization in which members can experience transcendence.

In taking this a step further, Stacey (2001) argues that as humans, our intentions are always emerging with our negotiations and interactions with each other, as the foundation of knowledge is empathy. Often this is implicit empathy (non-rational) and through critical 
spirituality, we can be more in touch with the "feeling of being" and with the notion of opening up possibilities of choice and more effective communication. Communicative interactions are the different views of what it means to be human involving our psychology and sociology. Rational (explicit) or cognitive psychology has to do with models and mental models of which the sender/receiver model of communication is the dominant model from which the meaning in the spoken word is taken together with response from another both consciously and subconsciously.

I see the implications of this as an awareness of "the other" or the non rational, (that is those things that are not readily cognitively apparent, such as our deeper motivations, which includes spirituality for some, and with the convergence of science and spirituality), as do many others, for organizational leadership. I believe a requirement, the leadership requirement, is for a leader to include purpose and meaning to the already established requirement for performance measured by fiscal acumen. Fiscal acumen is the discourse that has dominated the organizational agenda and can be seen as the outer/collective quadrant in Wilber's four quadrant model, Figure 1, (Wilber, 2000, p. 62). That being the monological, empirical, positivistic forms demonstrated by systems theory, Talcott Parsons, Auguste Comte et al. (Wilber, 2001, p. 51) and seems to have culminated in the "cult of performance" as I argued in foresight (Burke, 2004, pp. 47-56):

The basic assumption of the "cult of performance" is based on systems thinking, particularly that field of systems thinking that assumes that human systems are cybernetic systems and it is on this assumption that policy is built on. This has lead to the current organisational belief that has trapped us into thinking we can't say anything about performance through the contesting of different ways of thinking. (2004, p. 47)

Good performance is a necessary leadership outcome and, in the rational domain - the financial domain, easily measurable. A perceived difficulty, however, is that centered on the notion of the measurement of purpose and meaning. How do you measure the non-rational, the post modern, leadership and spirituality? Indeed, Inayatullah (2003/2004, p. 11) states:

But for spirituality to become associated with the quadruple bottom line [economic, environmental, social, spirituality], the bottom line will be finding measures. Measuring the immeasurable will not be an easy task.

Figure 1 Wilber's representative theorist

Some Representative Theorists

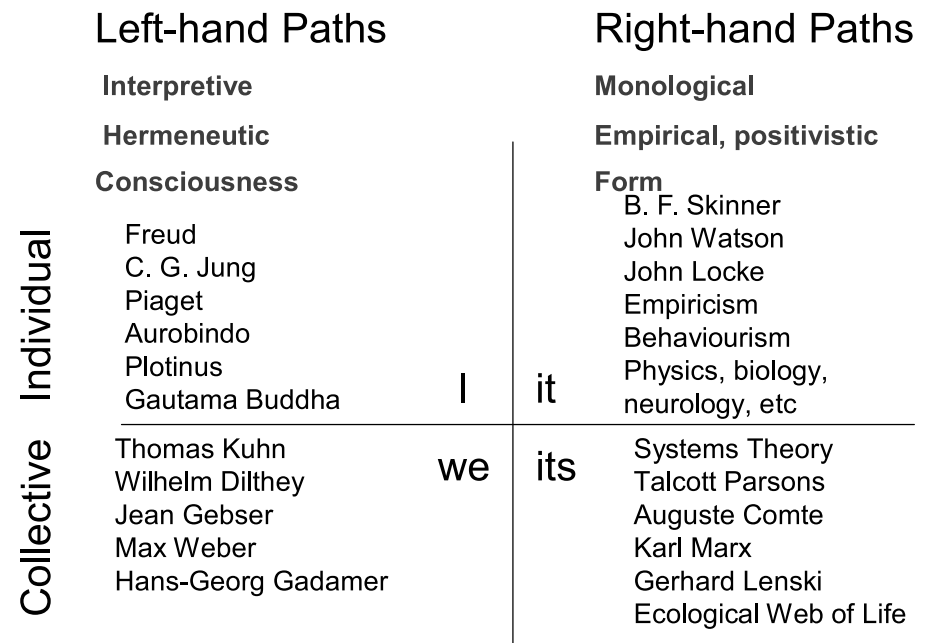

Source: Wilber (2001, p.51) 


\section{Does it even make sense to reduce spirituality to a measurable entity?}

I don't believe it does as by doing so it implies an "end" or a "goal" something that is achievable and by implication can be a greater achievement, as measured, for some than for others - e.g. I am more spiritual than you because my Spirituality 360 degree feedback tells me so, kind of argument. Indeed, I would argue what is our fascination with measurement? I can understand measurement against certain norms such as medical surgery and health practices. I can also see that measurement of academic achievement can be useful and of course it is useful for investors to be able to measure the worth of their investment. But measurement also brings with it less desirable outcomes. For example Inayatullah (2004, p. 84) argues in relationship to the measurement of academics that:

In University environments, one can expect far more avoiders and resisters than future natives. University jobs attract those who seek security, clear rules and regulations, vertical knowledge structures. They have a difficult time understanding changes in pedagogy. They search for consistency and stability and are shocked by the dramatic changes the university is undergoing. For future natives who embrace change, who live on the new, who seek to transform, who imagine other worlds, who know that other futures are possible, this seems fearful behaviour.

From an organizational leadership perspective I see this approach to change also. Although change management is a subject taught and an aspiration deemed desirable it is usually only directed at change that will improve performance. Change that improves morale through meaning attribution and caring is also seen as desirable providing it has a positive impact on the "bottom line" but it is considerably more difficult to measure from a rational perspective.

Lieberman, Yalom and Miles (Yalom, 1995, pp. 498-499) asked in 1973 "Which is the most effective leadership style?" and concluded that what leaders say they do is of little value. What is needed, they argued, is more accurate, empirically derived leader taxonomy (practice). Their research showed that a factor analysis of a large number of leader behavior variables (rated by observers) resulted in four basic leadership functions:

1. emotional stimulation: (challenging, confronting, activity, intrusive modeling by personal risk taking and high self disclosure);

2. caring: (offering support, affection, praise, protection, warmth, acceptance, genuineness, concern);

3. meaning attribution: (explaining, clarifying, interpreting, providing a cognitive framework for change, translating feelings and experiences into ideas); and

4. executive function: (setting limits, rules, norms, goals, managing time, pacing, stopping, interceding, suggesting procedures).

These four leadership functions had a clear and striking relationship to outcome.

Caring and meaning attribution had a linear relationship to positive outcome: the higher the caring and the higher the meaning attribution, the higher the positive outcome.

The other two functions, emotional stimulation and executive function had a curvilinear relationship to outcome - the rule of the golden mean: too much or too little of this leader behavior resulted in lower positive outcome. For example, too little leader emotional stimulation resulted in an unenergetic, devitalized group; too much stimulation (especially with insufficient meaning attribution) resulted in a highly emotionally charged climate with the leader pressing for more emotional interaction than the members could integrate. Too little executive function - a laissez-faire style - resulted in a bewildered, floundering group; too much resulted in a highly structured, authoritarian, arrhythmic group, which failed to develop a sense of member autonomy or a freely flowing interactional sequence.

The most successful leader, then, was one moderate in amount of stimulation and in expression of executive function and high in caring and meaning attribution. Both caring and meaning attribution seemed necessary: neither alone was sufficient to ensure success. This is depicted in Figure 2 which I sourced from Malcolm Davies and Phill Boas[1]. 


\section{LEADERSHIP EFFECTIVENESS}

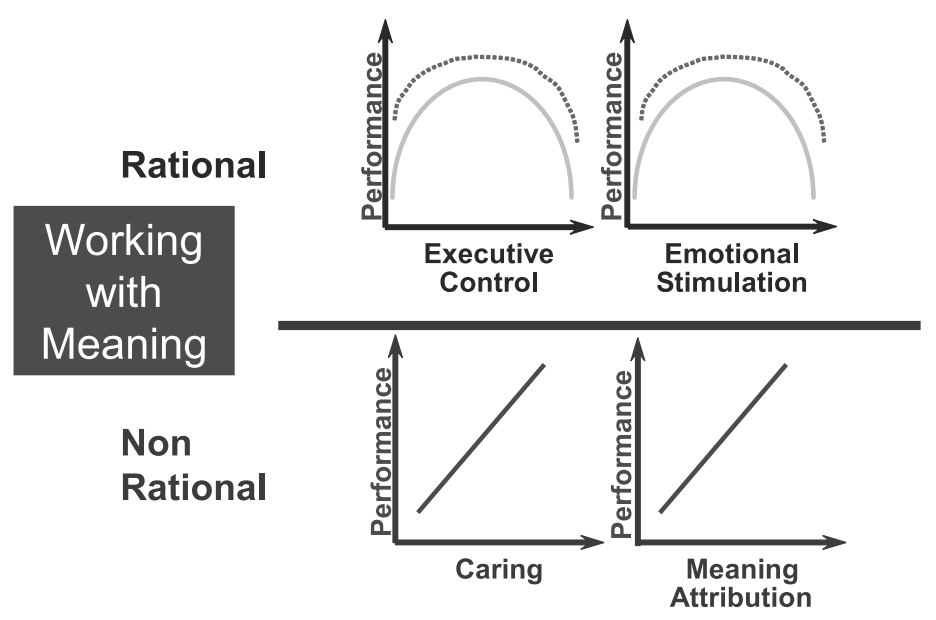

Source: Leiberman et al. (1973)

Ashis Nandy (1987, p. 95) asks: does commitment to one's culture have to be explicit and aggressive? Could it not be implicit and unconscious? I believe that meaning attribution is both implicit and unconscious and caring is a conscious leadership attribute that expresses itself through nonlocal connectivity, microvita, and spirituality.

\section{Can organizational leadership contribute to a better world?}

For me perhaps it is only through organizational leadership that a better world is possible. The ninth global challenge of the UN Millennium Project (2005) State of the Future is:

Capacity to decide. How can the capacity to make correct decisions be improved as the nature of work and institutions change?

We know the world is increasingly complex and that the most serious challenges are global in nature, yet we don't seem to know how to improve and deploy appropriate management techniques or Internet-based management tools and concepts fast enough to get on top of the situation. Since no government or other kind of institution acting alone can address any of the global challenges, interinstitutional decision making has to be developed. (www.acunu.org/millennium/Global_Challenges/chall-09.html)

Is interinstitutional decision making possible in a society that sees competition and winning at all costs as the measurement of success? Halal (2002, pp. 369-381) sees that evolution needs to proceed from the material to the spiritual and for him the world should be poised on the brink of maturity:

We will have to create sophisticated institutions that decentralize control to ordinary people, resolve differences with our adversaries, develop modest but adequate lifestyles, design international information networks, cultivate our wisdom, and pray for spiritual unity. In short, we have to grow up and behave as responsible adults. There is no alternative. (2002, p. 375)

Behaving as responsible adults brings with it the welfare of future generations. Although many large institutions are considered "anti- environmentalist" I am not convinced this is as widespread as many believe it is. Indeed nor does Jared Diamond (2005, p. 15):

Its adherents come especially from the world of big business and economics, but the equation "non-environmentalist" = "pro business" is imperfect; many business people consider themselves environmentalist, and many people sceptical of environmentalists' claims are not in the world of big business. 
The problem seems to me to be centered on our western worldview that growth is essential, that to consume more and more is beneficial to the workplace and as a result of this to society as a whole. This worldview is fraught with danger as it infers that we have the right to never ending consumption and that success is rightly based on this.

Another problem is the acceptance that executives are expected to work under increasing stress which no doubt will place enormous pressures on their family and on their personal relationships, and this has become the accepted rather than the excepted. The rise of the coaching and mentoring phenomena, now a multi-billion dollar a year business is evidence of this. Don't change the situation - that is the way it is, learning instead to cope with it is the mantra of many organizations today. This is nether healthy for the individuals concerned or healthy for the organization. It places rewards on commitment to the organization over commitment to personal health and to a personal life. The bottom line remains all invasive and this implies continued growth. As an individual we are told that we will benefit from this growth but we are expected to be prepared to sacrifice much of our individuality in the process. To be a company man or women is to be accepted as a valued individual and we will be festooned with the material trimmings to show this off.

Increasingly however we are seeing not only the dramatic increase in coaching and mentoring services but also a dramatic increase in psychological and psychotherapy services. Perhaps William Glasser, the renowned psychotherapist, may have identified part of the problem (Glasser in Ventura, 2006, pp. 58-59):

Human beings have a need no other living creatures share, and if we don't learn to deal with that need, we'll become extinct: our need for power. If we don't learn how to deal with our need for power, we're not ever going to have a mentally healthy society.

Manfred Kets de Vries also saw similarities between leadership coaching and psychotherapy (Kets de Vries, 2005, pp. 61-76) and advocated that there were benefits of leadership coaching in a group setting, because he claims that durable changes in leadership behavior are more likely to occur. Indeed Ralph Stacey (2003, pp. 328-329) claims that a therapy group is fundamentally like any other group. Individual and collective identities are continually iterated in the group as continuity and potential transformation:

As a therapist, one is not necessarily aiming for insight in terms of making the unconscious conscious. Indeed, healing may take place without insight as people talk differently to themselves and to each other without even being all that aware that they are doing so.

\section{Could spirituality produce a better organizational leadership paradigm?}

Joel Barker (1992, p. 140) claims that once the paradigm shifts everything goes back to zero, by which he means that you are back at the starting line with the new paradigm. He suggests we ask the question what today is impossible to do, but if it could be done, would fundamentally change your business? (The paradigm question)

In asking myself this question about leadership and spirituality I came up with what is impossible to change is the organizational paradigm centered on performance and economic rationalism.

Why is it impossible? (The worldview question). I came up with it is impossible because of the robustness of the western world view and our linear growth pattern developed through the centuries. Traditional notions of leadership actively seek people who foster imbalance and then exaggerate this imbalance in and through the organization. As a result amorality grows and what is encouraged is the growth of an undisciplined form of self-interest, in which winning is all that counts (Ralston-Saul, 1993, p. 121).

What would make it possible? (The reflective, futures and lateral thinking question). The result of the above is a deeply imbalanced world with a future of business-as-usual. However, through deep reflection at inner and outer levels, leadership can play an important role in changing the future, and today. It could be made possible by organisational leadership taking a humanistic approach to business. We would need to rethink what it means to be human (ontology). We would need to rethink what we mean by growth 
(epistemology, teleology). We would need to shift our activities from regulatory management to leadership (axiology, ideology).

How could I make it possible? (The transformational leadership question). This is the critical question. What am I personally prepared to do? What are we personally prepared to do? For a start it involves the search for identity. Who am I and what do I think I am doing? Who are we and what do we think we are doing? How have we come to be what we are now? What is my purpose? How will we come to be what we want to be? And can I be this ethically?

In approaching this question I was cognizant of what Kwame Anthony Appiah (2005, p. 170) stated:

The ethical self I have spoken of requires that, in making our lives, we accumulate evidence, form beliefs, identify options for action, predict and evaluate their outcomes, and act. Ideals of rationality, as they are usually understood, involve both, so to speak, calculation and information-both instrumental and cognitive dimensions. In a variety of ways, we all fall short of these ideals. And so I want to take up some questions about how we should understand the demands of rationality with respect to ethical success, and the broader notion of well-being.

How was I falling short of my ideals that through my teaching at my business school and through articles such as this, and presentations at conferences, with my quest for a new organizational leadership paradigm? Am I caught up in the business school mantra of marketing and branding?:

Since modern man experiences himself both as the seller and the commodity to be sold on the market, self-esteem depends on conditions beyond his control. If he is "successful," he is valuable; if he is not, he is worthless. (Fromm, 1947, p. 79 in Monte, 1999, p. 682)

The dilemma we experience at business schools to "deliver" an outcome in the shortest possible time that is measurable by participant's evaluation scores which in turn determineyour viability and status within the business school is a fearful pressure indeed. Do we entertain and create an "experience" that participants enjoy and thus score you highly, or do you challenge them, knowing that your challenge could be perceived by the participants as unsettling, creating anxiety and thus projecting denial leading to unfavorable scoring and evaluation?

The transformational leadership challenge for me is to be able to engage participants in a safe way, doing no harm, but at the same time challenging their assumptions, existing paradigms and worldviews, in order for them to be more comfortable with ambiguity, self questioning, challenge, and in the contesting of different ways of knowing.

\section{What could be a new leadership paradigm?}

In this transformation I believe we need organizational and political leaders, who can courageously engage others in conversations about what it means to be human, an ontological engagement. This requires leaders to challenge assumptions at all levels in an organization and in our society as a whole. The goal is for a return to the economy serving humanity as opposed to the current situation where humanity is serving the economy.

As a play on words I have used Figure 3 as a narrative metaphor with groups on discussions about leadership. It is meant as a dialogue comparing the competing images of the future concerning business and the future using the futures triangle (Inayatullah, 2005, p. 23).

This last point also echo's William Glasser's concern about the human addiction to power. Bill Emmott, the editor of The Economist, wrote (2004, p. 19):

That inequality of resources and power is another inherent weakness within capitalism. Indeed, one of capitalism's main motors is the very desire to create inequality, an inequality between those who succeed and those who fail. It is a competitive system. The incentive to create wealth, to build successful businesses, is an incentive to become unequal.

The power of narrative (Gnosis) is well known and forms not only the basis of good coaching, teaching, and therapy but I believe good leadership. Martyn Newman (2005: 36) claims that true leaders are really CSOs - Chief Storytelling Officers. Newman says: 
Figure 3

\section{CEO}

।

Leadership

|

Growth $=$ the current CEO mantra. But could it be:

CEO $=$ Courageously Engaging Others

Leading to

LEADERSHIP = Lets Employees Adapt Developments that are Ethically Responsible Sustaining Hope Inspiration and Purpose

Leading to

GROWTH = Greed Reduction therefore Opportunities are Widened which is Triumphing Humanity

And the stories they tell become the stuff of dreams. This is where real emotional capital originates. It's the energy generated by the story of what you and your business are capable of achieving. It's this energy that provides the focus, inspiration and meaning that ordinary people as well as organizations need to move forwards.

Through leaders emotional and spiritual intelligence I believe it is possible for a new leadership paradigm to emerge. This sees the leader as both effective in management through rational intelligence and in leadership using multiple intelligences. The new paradigm sees the leader place emphasis on correcting the cause of much that is wrong with leadership today that of the western worldview of the organization itself. This notion has spurned many of the devices that are used today in organizations, such as personality tests, 360 degree feedback tests and other instruments of evaluation. Many of these devices provide methods of coping with the effect of the effect rather than the cause of the effect. For example there is one instrument, the Hogan Development Survey (HDS) which assesses 11 common dysfunctional dispositions that interfere with a person's ability to build relationships. Although this is an excellent instrument and executives find it useful for their leadership development, it does reflect that side of organizational leadership that is less desirable. Yet many CEOs have achieved considerable success by their mastery of their dysfunctional selves, by their ability to use what we would perceive as unsociable behavior in "normal" life to great effect in organizational situations. For example:

And then, just when you thought the story of self aggrandizement couldn't get any stranger or uglier, we hear about the greed of the CEO - not of the next GE, but of the last GE! Jack Welch, whose name used to be synonymous with the gold standard of CEOs, turns out to be more interested in grabbing the gold than in upholding the standards. His imperial retirement package-revealed in the course of his already unpleasant divorce proceedings-only confirms the growing sense that most Americans have of the so-called leaders of corporate America: Who the hell do these people think they are? Let's throw the bums out. ("More Power to Them" From the Founders of "Fast Company" October, 2002)

The new leadership paradigm asks the leader to be the one who can show what it means to be human, what it means to be authentic and how by modeling behavior that sees other humans, other life forms, Gaian worldviews, and other ways of knowing, other epistemologies, as not only the most important aspect of any organization but as the way of gaining deeper insights into their spiritual selves and into the spiritual lives of others through microvita:

Don't aim at success - the more you aim at it and make it a target, the more you are going to miss it. For success, like happiness, cannot be pursued; it must ensue ... as the unintended side effect of one's personal dedication to a cause greater than oneself ... (Viktor Frankl in Man's Search for Meaning). 


\section{Note}

1. Malcolm Davies is Managing Director of Learning At Work and Phill Boas is a Program Director at Melbourne Business School, Mt Eliza Centre for Executive Education. The "Green Line" theory developed and used by Phill Boas, as a model for understanding the connectivity between our rational and non-rational worlds. It is complimentary to Wilber's four quadrant thinking as it is a pathway for guiding us through a "wholeness" exploration of a question or problem.

\section{References}

Appiah, K.A. (2005), The Ethics of Identity, Princeton University Press, Princeton, NJ.

Bambling, M. (2006), "Mind, body and heart: psychotherapy and the relationship between mental and physical health", Psychotherapy in Australia, Vol. 12 No. 2.

Barker, J.A. (1992), Paradigms: The Business of Discovering the Future, HarperBusiness, New York, NY.

Blackburn, S. (1999), Think, Oxford University Press, Oxford.

Bullock, I. (2002), "The CEO refresher", available at: www.refresher.com/!spiritualintelligence.html

Burke, R. (2004), "The cult of performance: what are we doing when we don't know what we are doing?", foresight, Vol. 6 No. 1, pp. 47-56.

Burke, R. (2006), "A role for business schools in leadership, futures and ethics", Journal of Futures Studies, Vol. 10 No. 4, pp. 71-82.

Diamond, J. (2005), "Collapse: how societies choose to fail or survive", Penguin, Harmondsworth.

Emmott, B. (2004), 20:21 Vision: The Lessons of the 20th Century for the 21st, Penguin Books, Harmondsworth.

Fastcompany.com (2002), "More power to them", Fast Company, October.

Frankl, V. (1997), Man's Search for Meaning, Simon \& Schuster, New York, NY.

Fromm, E. (1947), Man for Himself, Fawcett Books, Greenwich, CT, in Monte, C.F. and Sollod, R.N., Beneath the Mask: An Introduction to Theories of Personality, 6th ed., Harcourt Brace, New York, NY.

Glasser, W. (2006), in Ventura M., "The wisdom of the elders: psychotherapy's elders throw down the gauntlet”, Psychotherapy Networker, March/April, pp. 58-9.

Halal, W.E. (2002), "Prophets of a high-tech age: futures studies through the eyes of a futurist", in Dator, J.A. (Ed.), Advancing Futures: Futures Studies in Higher Education, Praeger, New York, NY.

Hames, R.D. and Callanan, G. (1997), Burying the 20th Century, Business and Professional Publishing, Sydney.

Inayatullah, S. (2003/2004), "Spirituality as the fourth bottom line", New Renaissance, Vol. 12 No. 2.

Inayatullah, S. (2004), "Future avoiders, migrants and natives", Journal of Futures Studies, Vol. 9 No. 2 , pp. 83-6.

Inayatullah, S. (2005), Questioning the Future: Methods and Tools for Organizational and Societal Transformation, Tamkang University, Taiwan.

Kets de Vries, M.F.R. (2005), "Leadership group coaching in action: the zen of creating high performance teams", Academy of Management Executive, Vol. 19 No. 1.

Laszlo, E. (2006), Science and the Reenchantment of the Cosmos, Inner Traditions, Rochester, VT.

Lovelock, J. (2006), The Revenge of Gaia, Penguin, Harmondsworth.

Nandy, A. (1987), Traditions, Tyranny and Utopias: Essays in the Politics of Awareness, Oxford University Press, Delhi.

Newman, M. (2005), Emotional Capitalists: The New Leaders, RocheMartin Institute, St Kilda.

Ralston-Saul, J. (1993), Voltaire's Bastards: The Dictatorship of Reason in the West, Penguin Books, Toronto, p. 121.

Ralston-Saul, J. (2005), The Collapse of Globalism and the Reinvention of the World, Viking, Auckland. 
Stacey, R.D. (2001), Complex Responsive Processes in Organisations - Learning and Knowledge Creation, Routledge, London.

Stacey, R.D. (2003), Complexity and Group Processes: A Radically Social Understanding of Individuals, Brunner-Routledge, London.

UN Millennium Project (2005), State of the Future, AC/UNU Millennium Project Publications, available at: www.acunu.org/millennium/issues.html

Watson, P. (2005), Ideas: a History from Fire to Freud, Weidenfeld \& Nicolson, London.

Weber, M. (1904/1905), Die protestantische Ethik und der Geist des Kapitalismus ((The Protestant Ethic and the Spirit of Capitalism)), Routledge, London.

Wilber, K. (2000), Integral Psychology: Consciousness, Spirit, Psychology, Therapy, Shambhala, Boston, MA.

Wilber, K. (2001), A Theory of Everything, Shambhala, Boston, MA.

Wilber, K. (2003), Boomeritis, Shambhala, Boston, MA.

Yalom, I.D. (1995), The Theory and Practice of Group Psychotherapy, 4th ed., Basic Books, New York, NY.

Zohar, D. and Marshall, I. (2000), SQ Connecting with Our Spiritual Intelligence, Bloomsbury Publishing, London.

\section{Further reading}

Lieberman, M., Yalom, I. and Miles, M. (1973), Encounter Groups: First Facts, Basic Books, New York, NY.

\section{Corresponding author}

Robert Burke can be contacted at: r.burke@mbs.edu

To purchase reprints of this article please e-mail: reprints@emeraldinsight.com Or visit our web site for further details: www.emeraldinsight.com/reprints 